\title{
Comparative Evaluation of Antimicrobial Efficacy of Calcium Hydroxide Mixed with Different Vehicles on Enterococcus faecalis - an in Vitro Study
}

\author{
Neha Sharma M ${ }^{1}$, Anjaneyulu K² and Muralidharan NP3 \\ ${ }^{1}$ Saveetha Dental College, Saveetha Institute of Medical and Technical \\ Sciences, Saveetha University, Chennai - 600077, India \\ ${ }^{2}$ Reader, Department of Conservative Dentistry and Endodontics, Saveetha Dental College, Saveetha \\ Institute of Medical and Technical Sciences, Saveetha University, Chennai - 600077, India \\ ${ }^{3}$ Reader, Department of Microbiology, Saveetha Dental College, Saveetha Institute of Medical and \\ Technical Sciences, Saveetha University Chennai - 600077, India
}

\section{ABSTRACT}

Calcium hydroxide $[\mathrm{Ca}(\mathrm{OH}) 2]$ has been popularly used as an intracanal medication because of its good antibacterial properties and biocompatibility. The aim of this study is to compare the antimicrobial efficacy of $\mathrm{CaOH}$ and vehicles on E. faecalis - An in-vitro study. The study was done by cutting wells in Tryptose soya agar and filling the wells with the different combinations of medicaments. The bacterial suspension of standard strains of E. faecalis is spread on the entire surface of the media using a sterile swab. The three different plates were incubated at 37 degree Celsius aerobically for 24hrs. After the incubation, the zone of inhibition is measured and tabulated for each mixture. There was a significant difference in the antimicrobial activity of calcium hydroxide mixed with chlorhexidine against Enterococcus faecalis. This study showed that the combination of calcium hydroxide with chlorhexidine gluconate showed relatively higher antimicrobial action against $\mathrm{E}$. faecalis when compared to the other two combinations of medicaments.

KEY WORDS: CALCIUM HYDROXIDE, CHLORHEXIDINE, ENTEROCOCCUS, MEDICAMENT, ROOT CANAL.

\section{INTRODUCTION}

Pulp interventions combine a pulp treatment technique and a medicament. The primary objective of pulp interventions is to maintain the integrity of the tooth and the health of its supporting tissues. Several medicaments are available for the obturation of the decontaminated

\section{ARTICLE INFORMATION}

*Corresponding Author: Kanjaneyulu.sdc@saveetha.com Received 15th June 2020 Accepted after revision 10th August 2020 Print ISSN: 0974-6455 Online ISSN: 2321-4007 CODEN: BBRCBA

Thomson Reuters ISI Web of Science Clarivate Analytics USA and Crossref Indexed Journal

\section{Clarivate
Analytics}

NAAS Journal Score 2020 (4.31) SJIF: 2020 (7.728)

A Society of Science and Nature Publication,

Bhopal India 2020. All rights reserved.

Online Contents Available at: http//www.bbrc.in/

Doi: http://dx.doi.org/10.21786/bbrc/13.7/67 surfaces or canals, the most frequently used are mineral trioxide aggregate (MTA), calcium hydroxide, formocresol or ferric sulphate (Smaïl-Faugeron et al., 2018). Calcium hydroxide intracanal dressing is considered as the most favorable antimicrobial agent. Several well controlled in-vitro and in-vivo studies have shown intra-canal reduction of microbial population or at least inhibit bacterial proliferation. Calcium hydroxide also alters bacterial cell walls and denatures a potent endotoxin, lipopolysaccharide, thereby rendering it less antigenic (Anjaneyulu and Nivedhitha, 2014). Calcium hydroxide has been shown to create superficial necrosis which inhibits bleeding and fluid loss however, problems with internal resorption and less long-term success were reported (Huth et al., 2012). 
In addition to the widespread clinical use of $\mathrm{Ca}(\mathrm{OH}) 2$, studies have tested various $\mathrm{Ca}(\mathrm{OH}) 2$ formulations and mixtures of $\mathrm{Ca}(\mathrm{OH}) 2$ powder with different substances in an attempt to improve $\mathrm{Ca}(\mathrm{OH}) 2$ performance (L. L. C. E. Silva et al., 2019). $\mathrm{Ca}(\mathrm{OH}) 2$ is composed of calcium ions, which react with the carbon dioxide present in tissues, producing calcite granules. This process leads to the accumulation of fibronectin, which allows cell adhesion and differentiation, thus resulting in the formation of mineralized tissue (Araújo et al., 2018). However, $\mathrm{Ca}(\mathrm{OH}) 2$ inactivates endotoxin and impedes the increase in cytokine chemical inflammatory mediators to inhibit periapical inflammation after a root canal cleaning procedure.

The antimicrobial activity of $\mathrm{Ca}(\mathrm{OH}) 2$ is dependent on the release of hydroxyl ions in an aqueous environment and the lethal effects of hydroxyl ions on bacterial cells are probably due to damage to the bacterial cytoplasmic membrane, denaturation of proteins, or damage to the DNA (Mohammadi et al., 2012). For calcium hydroxide to act effectively as an intracanal dressing, the hydroxyl ions must be able to diffuse through dentine and pulpal tissue remnants (Siqueira and Lopes, 1999). CHX is a positively charged hydrophobic and lipophilic molecule that interacts with phospholipids and lipopolysaccharides on the cell membrane of bacteria and then enters the cell through some type of active or passive transport mechanism. Its efficacy is due to the interaction of positive charge of the molecule and negatively charged phosphate groups on the microbial cell walls, thereby altering the cells' osmotic equilibrium. This increases the permeability of the cell wall, which allows the CHX molecule to penetrate into the bacteria (Mohammadi and Abbott, 2009). In a study done by Oncag et al. it was stated that the $2 \%$ chlorhexidine gluconate and Cetrexidin was significantly more effective on $E$. faecalis than the 5.25\% $\mathrm{NaOCl}$ at 5 min (Oncag et al., 2003).

E. faecalis a normal inhabitant of the oral cavity; . E. faecalis is associated with different forms of periradicular disease including primary endodontic infections and persistent infections. In the category of primary endodontic infections, E. faecalis is associated with asymptomatic chronic periradicular lesions significantly more often than with acute periradicular periodontitis or acute periradicular abscesses (Stuart et al., 2006). It was also found that E. faecalis was significantly more associated with asymptomatic cases than with symptomatic cases (Rocas et al., 2004). We have numerous highly cited publications on well designed clinical trials and lab studies (Azeem and Sureshbabu, 2018; Govindaraju et al., 2017; Janani and Sandhya, 2019; Jenarthanan and Subbarao, 2018; Khandelwal and Palanivelu, 2019; Malli Sureshbabu et al., 2019; Manohar and Sharma, 2018; Nandakumar and Nasim, 2018; Poorni et al., 2019; Rajakeerthi and Ms, 2019; Rajendran et al., 2019; Ramarao and Sathyanarayanan, 2019; Siddique et al., 2019a, 2019b; Siddique and Nivedhitha, 2019; Teja et al., 2018). This has provided the right platforms for us to pursue the current study. Hence the aim of this study is to compare the antimicrobial efficacy of $\mathrm{CaOH}$ and vehicles on E. faecalis - An in-vitro study.

\section{MATERIAL AND METHODS}

Preparation of bacterial suspension: Standard strain of E. faecalis is grown in Brain- heart infusion agar. Fresh cultures are used to make suspension in sterile saline with turbidity matching 0.5 Mc Farland standard. $100 \mathrm{ml}$ is transferred to the plates and they are spread on the entire surface using a sterile swab.

Agar well diffusion method: The test is done on Tryptose soya agar by cutting well using a $4 \mathrm{~mm}$ metal tube. The agar is poured and when it is set, the flame sterilized tube is used to cut the well. The wells were cut without removing the agar at the bottom level. The bacterial suspension of standard strains of $E$. faecalis is spread on the entire surface of the media using a sterile swab. Three different plates are used for each group, with each plate containing four wells. The three different mixtures are placed in the well occupying the entire capacity and touching the boundaries. Then the plates were incubated at 37 degree Celsius aerobically for 24hrs. After the incubation, the zone of inhibition is measured and tabulated for each mixture.

Statistical analysis: The data was tabulated and assessed for statistical significance using the SPSS software. Percentage, mean, standard deviation, frequency of parameters were employed in the analysis. Anova test and Post Hoc test was used to detect the significance between the different groups of intracanal medicaments. $P$ value less than 0.05 was considered to be statistically significant.

\section{RESULTS AND DISCUSSION}

A total of three groups were included in this study: $\mathrm{Ca}(\mathrm{OH})_{2}+$ Saline, $\mathrm{Ca}(\mathrm{OH})_{2}+$ Chlorhexidine and $\mathrm{Ca}(\mathrm{OH}) 2$ + Eugenol. An equally measured quantity of each of these groups was tested for its antibacterial efficacy. The zone of inhibition of each of these groups were measured from the culture plates and were tabulated. The region without bacterial colonies that is the Zone of Inhibition will be in a different color as compared to other regions of bacterial growth. There is a marked difference and easily visible to the naked eye [Figure $1,2,3]$. The measurement of the diameter of this Zone of Inhibition will conform if the medicament is effective in treating the patient or not. Larger the diameter more will be the effectiveness of the medicament. From the study it was found that, the mean zone of inhibition for the group $\mathrm{Ca}(\mathrm{OH})_{2}+$ Saline was $18 \mathrm{~mm}, 25.5 \mathrm{~mm}$ for

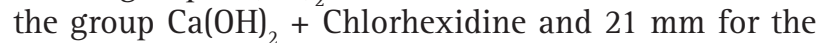
group $\mathrm{Ca}(\mathrm{OH})_{2}+$ Eugenol [Figure 4]. From the graph it is evident that the maximum zone of inhibition was shown in the group $\mathrm{Ca}(\mathrm{OH})_{2}+$ Chlorhexidine. The descriptive data for the zone of inhibition of each of these groups is shown in Table 1.

On doing the Anova test, it was found that there was a significant difference between the three groups of 
$\mathrm{Ca}(\mathrm{OH})_{2}$ ( $\mathrm{p}$ value $\left.=0.001<0.05\right) \quad$ [Table 2]. On doing the Post Hoc test, it was found that there was significant difference in antibacterial effects between the groups $\mathrm{Ca}(\mathrm{OH})_{2}+$ Saline and $\mathrm{Ca}(\mathrm{OH})_{2}+$ Chlorhexidine ( $\mathrm{p}$ value
$0.001<0.05)$. The comparison of antibacterial effects between the groups $\mathrm{Ca}(\mathrm{OH})_{2}+$ Chlorhexidine and $\mathrm{Ca}(\mathrm{OH})_{2}$ + Eugenol was also found to be statistically significant (p value $0.01<0.05$ ) [Table 3].

\begin{tabular}{l} 
Table 1. Table representing the descriptive statistics of the zone of inhibition of each group. From \\
the table it is evident that the combination of $\mathrm{Ca}(\mathrm{OH}) 2$ with Chlorhexidine showed maximum zone \\
of inhibition when compared to the other groups. \\
\hline \\
\hline
\end{tabular}

Table 2. Table shows the results from the one-way Anova test between the three groups. From the graph it can be interpreted that there is a statistically significant difference between the three groups. ( $p$ value $=0.001<0.05$ ) .

\begin{tabular}{|l|c|c|c|c|c|}
\hline $\begin{array}{l}\text { Sum of } \\
\text { Squares }\end{array}$ & df & $\begin{array}{c}\text { Mean } \\
\text { Square }\end{array}$ & & F & Sig. \\
\hline Between Groups & 114.000 & 2 & 57.000 & 20.520 & .000 \\
\hline Within Groups & 25.000 & 9 & 2.778 & & \\
\hline Total & 139.000 & 11 & & & \\
\hline
\end{tabular}

Table 3: Table representing the results from the Post Hoc test done between the three groups to compare their significance. The combination of Calcium hydroxide with chlorhexidine was found to be significantly better than calcium hydroxide with saline ( $p$ value $=0.001<0.05)$. The combination of calcium hydroxide with chlorhexidine was also found to be significantly better than Calcium
Figure 1: Culture plate showing the visible zone of inhibition produced by the group $\mathrm{Ca}(\mathrm{OH}) 2+$ Saline against E. faecalis

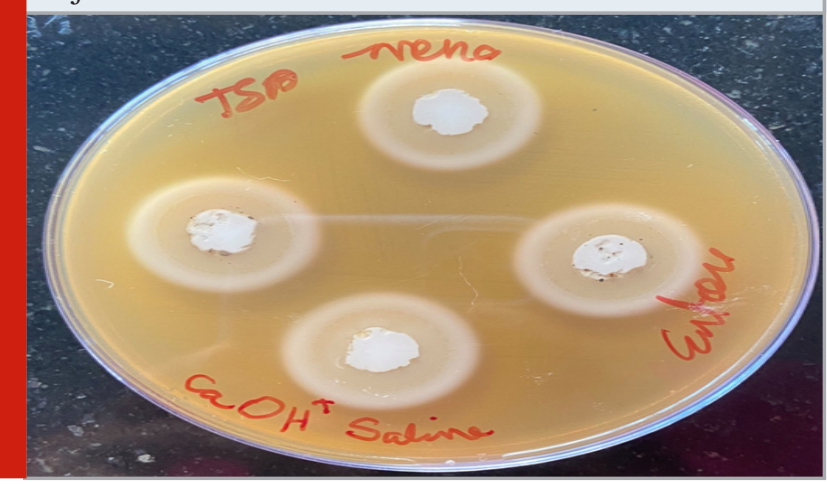

hydroxide with eugenol ( $p$ value $=0.01<0.05)$. There was no significant difference between the groups Calcium hydroxide and Saline and Calcium hydroxide and eugenol ( $p$ value $=0.073>0.05)$.

Table 3. Table representing the results from the Post Hoc test done between the three groups to compare their significance. The combination of Calcium hydroxide with chlorhexidine was found to be significantly better than calcium hydroxide with saline ( $p$ value $=0.001<0.05$ ). The combination of calcium hydroxide with chlorhexidine was also found to be significantly better than Calcium hydroxide with eugenol ( $p$ value= $0.01<0.05)$. There was no significant difference between the groups Calcium hydroxide and Saline and Calcium hydroxide and eugenol ( $p$ value $=0.073>0.05$ ).

\begin{tabular}{|l|c|c|c|c|}
\hline (I) Groups & (J) Groups & $\begin{array}{c}\text { Mean } \\
\text { Difference (I-J) }\end{array}$ & Std. Error & Sig. \\
\hline \multirow{2}{*}{$\mathrm{Ca}(\mathrm{OH})_{2}+$ Saline } & $\mathrm{Ca}(\mathrm{OH})_{2}+$ Chlorhexidine & $-7.500^{*}$ & 1.179 & .000 \\
& $\mathrm{Ca}(\mathrm{OH})_{2}+$ Eugenol & -3.000 & 1.179 & .073 \\
\hline $\mathrm{Ca}(\mathrm{OH})_{2}+$ Chlorhexidine & $\mathrm{Ca}(\mathrm{OH})_{2}+$ Saline & $7.500^{*}$ & 1.179 & .000 \\
& $\mathrm{Ca}(\mathrm{OH})_{2}+$ Eugenol & $4.500^{*}$ & 1.179 & .010 \\
\hline $\mathrm{Ca}(\mathrm{OH})_{2}+$ Eugenol & $\mathrm{Ca}(\mathrm{OH})_{2}+$ Saline & 3.000 & 1.179 & .073 \\
& $\mathrm{Ca}(\mathrm{OH})_{2}+$ Chlorhexidine & $-4.500^{*}$ & 1.179 & .010 \\
\hline
\end{tabular}

*. The mean difference is significant at the 0.05 level. 
Enterococcus faecalis (E. faecalis) is one of the common pathogens recovered from patients suffering from recurrent root canal treatment failures. The ability of $E$. faecalis to form biofilm both on the root canal walls and within the dentinal tubules contributes to their persistence. Moreover, the complex structure of the root canal system allows bacterial evasion from the immune system and antibiotics (Shlezinger et al., 2019). In dentistry, E. faecalis is particularly prevalent in root canals with a diagnosis of apical periodontitis and has been implicated as the main pathogen in secondary endodontic infections. In endodontic treatment, intracanal medications are used as adjuvants during biomechanical preparation (S. Silva et al., 2019). Calcium hydroxide, as an intracanal disinfectant with increasing application, can release hydroxyl ions which are strongly alkaline. Its abilities have been reported to destroy the cell membrane and protein structure of bacteria and can disinfect the root canal (Jia et al., 2019). Despite its excellent properties, the buffering action of dentin can neutralize the antimicrobial activity of $\mathrm{CH}$ at deeper layers of dentinal tubules, and E. faecalis resistance to this medicament has consequently been demonstrated (Lei et al., 2016).

Figure 2: Culture plate showing the visible zone of inhibition produced by the group $\mathrm{Ca}(\mathrm{OH})_{2}+\mathrm{CHX}$ against E. faecalis

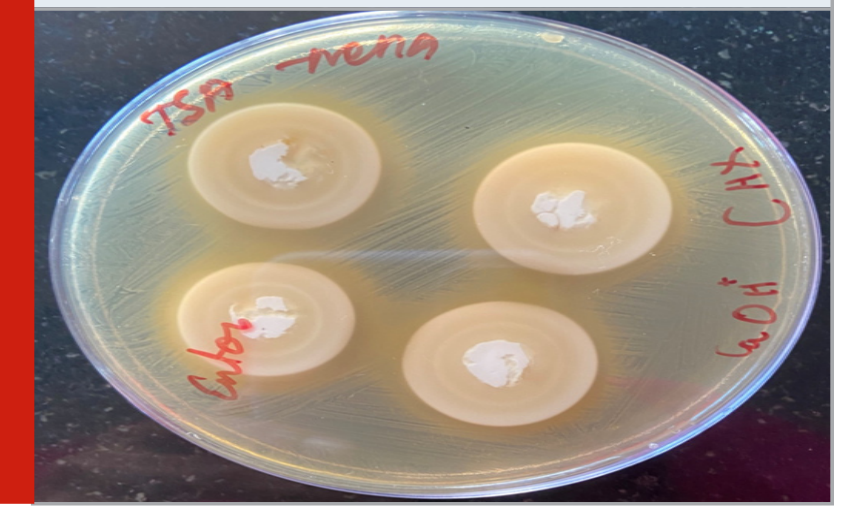

Figure 3: Culture plate showing the visible zone of inhibition produced by the group $\mathrm{Ca}(\mathrm{OH})_{2}+$ Eugenol against E. faecalis

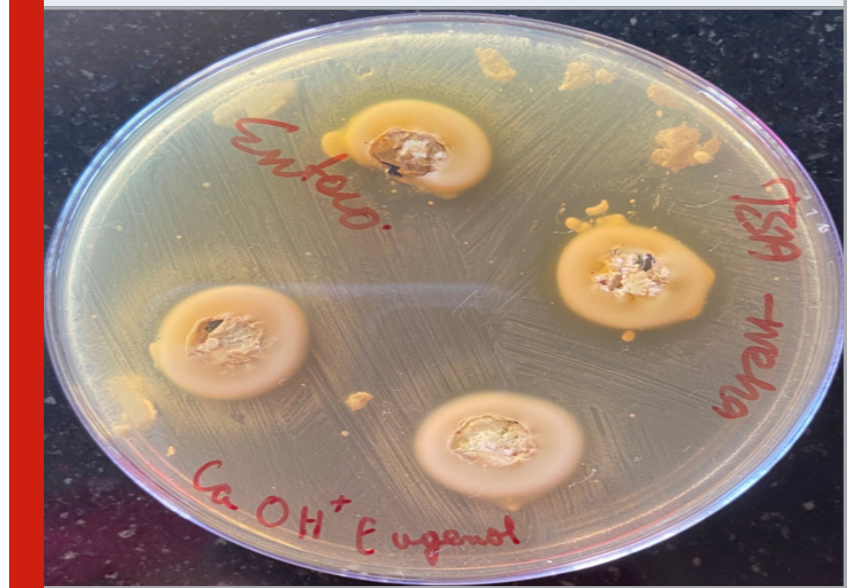

In this study the efficacy of calcium hydroxide when mixed with different vehicles such as saline, chlorhexidine and eugenol is tested. Eugenol is a parasubstituted phenolic compound contained in several plants including clove and bay leaves and has been widely used as an analgesic and anti-inflammatory drug to treat toothache and pulpitis in the dental clinic. It is used in combination with zinc oxide as a pulp-capping agent, temporary filling and a root canal sealer (Tammannavar et al., 2013). CHX can be applied clinically as antimicrobial agent during all phases of the root canal preparation, including the disinfection of the operatory field; during the enlargement of the canals orifices; removal of necrotic tissues before performing the root canal length determination; in the chemomechanical preparation prior to the foraminal patency and enlargement; as an intracanal medicament alone or combined with other substances (i.e. calcium hydroxide - CH) (Gomes et al., 2013).

Figure 4: Bar graph representing the mean of zones of inhibition of the three groups. $\mathrm{X}$ axis represents the combination of $\mathrm{Ca}(\mathrm{OH})_{2}$ with three different vehicles and $\mathrm{Y}$ axis represents the zone of inhibition against the bacteria in millimeter $(\mathrm{mm})$. Green colour represents the group $\mathrm{Ca}(\mathrm{OH})_{2}+$ Saline, blue colour represents the group $\mathrm{Ca}(\mathrm{OH})_{2}+$ Chlorhexidine and purple colour represents the group $\mathrm{Ca}(\mathrm{OH})_{2}+$ Eugenol. From the graph it was evident that the maximum zone of inhibition of an average of 25.5 $\mathrm{mm}$ was seen in $\mathrm{Ca}(\mathrm{OH})_{2}+$ Chlorhexidine mixture followed by $21 \mathrm{~mm}$ in $\mathrm{Ca}(\mathrm{OH})_{2}+$ Eugenol mixture.

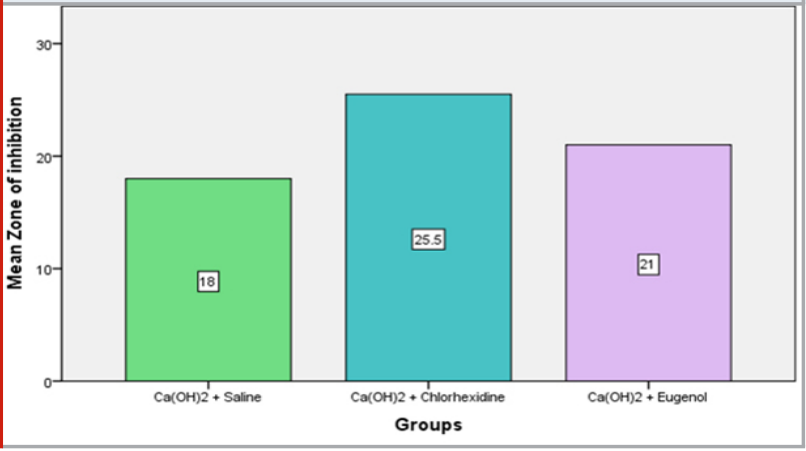

In this present study, it was found that the combination of Calcium hydroxide with Chlorhexidine showed greater zones of inhibition when compared to the other two groups. This is in accordance with a study done by Rao et al which showed that there is a significant decrease in colony forming units in the group $\mathrm{Ca}(\mathrm{OH}) 2$ and $\mathrm{CHX}$ (Muralidhar and Soonu, n.d.). Another study showing similar results stated that by mixing $\mathrm{Ca}(\mathrm{OH}) 2$ with $\mathrm{CHX}$, the antimicrobial activity of $\mathrm{Ca}(\mathrm{OH}) 2$ can be increased (Kim and Kim, 2014). Although this is contradicted by a study which stated that CHX does not increase the antibacterial effect of Calcium Hydroxide (Saatchi et al., 2014). This may be due to deprotonation of CHX at high $\mathrm{pH}$, which reduces its solubility and alters its interaction with bacterial surfaces as a result of the altered charge of the molecule. Another study by Carmen et al stated that higher concentration of $\mathrm{CHX}(2 \%)$ alone showed 
a greater capacity to inhibit E. faecalis growth (FerrerLuque et al., 2014). A previous study also showed that the addition of chlorhexidine with calcium hydroxide did not interfere with the chemical properties of calcium hydroxide (Signoretti et al., 2011).

The filling ability of calcium hydroxide pastes is probably more important in retarding root canal recontamination than the chemical effect. Because calcium hydroxide has low water solubility, it is slowly dissolved in saliva, remaining in the canal for a long period, delaying the bacterial progression toward the apical foramen (Siqueira and Lopes, 1999). Despite the vehicle used, calcium hydroxide seems to act as an effective physical barrier.

\section{CONCLUSION}

Within the limitations of this study in vitro study it can be concluded that there is significant difference in the antimicrobial activity of calcium hydroxide mixed with chlorhexidine against Enterococcus faecalis. There was also a statistical difference between the groups $\mathrm{Ca}(\mathrm{OH})_{2}$ + Saline and $\mathrm{Ca}(\mathrm{OH})_{2}+$ Chlorhexidine and $\mathrm{Ca}(\mathrm{OH})_{2}+$ Eugenol and $\mathrm{Ca}(\mathrm{OH})_{2}+$ Chlorhexidine.

\section{ACKNOWLEDGEMENTS}

The authors would like to acknowledge the help and support rendered by the Department of Conservative Dentistry and Endodontics and Information Technology of Saveetha Dental College and Hospitals and the management for their constant assistance with the research.

\section{Conflict of Interest: Nil}

\section{REFERENCES}

Anjaneyulu, K., Nivedhitha, M.S., 2014. Influence of calcium hydroxide on the post-treatment pain in Endodontics: A systematic review. J. Conserv. Dent. 17, 200-207.

Araújo, L.B., Cosme-Silva, L., Fernandes, A.P., Oliveira, T.M. de, Cavalcanti, B. das N., Gomes Filho, J.E., Sakai, V.T., 2018. Effects of mineral trioxide aggregate, BiodentineTM and calcium hydroxide on viability, proliferation, migration and differentiation of stem cells from human exfoliated deciduous teeth. J. Appl. Oral Sci. 26, e20160629.

Azeem, R.A., Sureshbabu, N.M., 2018. Clinical performance of direct versus indirect composite restorations in posterior teeth: A systematic review. J. Conserv. Dent. 21, 2-9.

Ferrer-Luque, C.M., Arias-Moliz, M.T., Ruíz-Linares, M., García, M.E.M., Baca, P., 2014. Residual activity of cetrimide and chlorhexidine on Enterococcus faecalisinfected root canals. International Journal of Oral Science.

Gomes, B.P.F.A., Brenda P F, Vianna, M.E., Zaia, A.A., Almeida, J.F.A., Souza-Filho, F.J., Ferraz, C.C.R., 2013. Chlorhexidine in Endodontics. Brazilian Dental
Journal.

Govindaraju, L., Neelakantan, P., Gutmann, J.L., 2017. Effect of root canal irrigating solutions on the compressive strength of tricalcium silicate cements. Clin. Oral Investig. 21, 567-571.

Huth, K.C., Hajek-Al-Khatar, N., Wolf, P., Ilie, N., Hickel, R., Paschos, E., 2012. Long-term effectiveness of four pulpotomy techniques: 3-year randomised controlled trial. Clinical Oral Investigations.

Janani, K., Sandhya, R., 2019. A survey on skills for cone beam computed tomography interpretation among endodontists for endodontic treatment procedure. Indian J. Dent. Res. 30, 834-838.

Jenarthanan, S., Subbarao, C., 2018. Comparative evaluation of the efficacy of diclofenac sodium administered using different delivery routes in the management of endodontic pain: A randomized controlled clinical trial. J. Conserv. Dent. 21, 297301.

Jia, L., Zhang, X., Shi, H., Li, T., Lv, B., Xie, M., 2019. The Clinical Effectiveness of Calcium Hydroxide in Root Canal Disinfection of Primary Teeth: A Meta-Analysis. Medical Science Monitor.

Khandelwal, A., Palanivelu, A., 2019. Correlation Between Dental Caries And Salivary Albumin In Adult Population In Chennai: An In Vivo Study. BDS 22, 228-233.

Kim, D., Kim, E., 2014. Antimicrobial effect of calcium hydroxide as an intracanal medicament in root canal treatment: a literature review - Part I.In vitrostudies. Restorative Dentistry \& Endodontics.

Lei, L., Shao, M., Yang, Y., Mao, M., Yang, Y., Hu, T., 2016. Exopolysaccharide dispelled by calcium hydroxide with volatile vehicles related to bactericidal effect for root canal medication. J. Appl. Oral Sci. 24, 487-495. Malli Sureshbabu, N., Selvarasu, K., V, J.K., Nandakumar, M., Selvam, D., 2019. Concentrated Growth Factors as an Ingenious Biomaterial in Regeneration of Bony Defects after Periapical Surgery: A Report of Two Cases. Case Rep. Dent. 2019, 7046203.

Manohar, M.P., Sharma, S., 2018. A survey of the knowledge, attitude, and awareness about the principal choice of intracanal medicaments among the general dental practitioners and nonendodontic specialists. Indian J. Dent. Res. 29, 716-720.

Mohammadi, Z., Abbott, P.V., 2009. The properties and applications of chlorhexidine in endodontics. International Endodontic Journal.

Mohammadi, Z., Shalavi, S., Yazdizadeh, M., 2012. Antimicrobial Activity of Calcium Hydroxide in Endodontics: A Review. Chonnam Medical Journal. Muralidhar, T., Soonu, C.S., n.d. Comparative Evaluation of Antimicrobial Efficacy of Calcium Hydroxide and Chlorhexidine Gutta Percha Points against E. faecalis and S. mutans - An In Vitro Study.

Nandakumar, M., Nasim, I., 2018. Comparative evaluation of grape seed and cranberry extracts in 
preventing enamel erosion: An optical emission spectrometric analysis. J. Conserv. Dent. 21, 516-520. Oncag, O., Hosgor, M., Hilmioglu, S., Zekioglu, O., Eronat, C., Burhanoglu, D., 2003. Comparison of antibacterial and toxic effects of various root canal irrigants. International Endodontic Journal.

Poorni, S., Srinivasan, M.R., Nivedhitha, M.S., 2019. Probiotic strains in caries prevention: A systematic review. J. Conserv. Dent. 22, 123-128.

Rajakeerthi, R., Ms, N., 2019. Natural Product as the Storage medium for an avulsed tooth - A Systematic Review. Cumhuriyet Dental Journal 22, 249-256.

Rajendran, R., Kunjusankaran, R.N., Sandhya, R., Anilkumar, A., Santhosh, R., Patil, S.R., 2019. Comparative Evaluation of Remineralizing Potential of a Paste Containing Bioactive Glass and a Topical Cream Containing Casein Phosphopeptide-Amorphous Calcium Phosphate: An in Vitro Study. Pesqui. Bras. Odontopediatria Clin. Integr. 19, 1-10.

Ramarao, S., Sathyanarayanan, U., 2019. CRA Grid - A preliminary development and calibration of a paperbased objectivization of caries risk assessment in undergraduate dental education. J. Conserv. Dent. 22, 185-190.

Rocas, I., Siqueirajr, J., Santos, K., 2004. Association of Enterococcus faecalis With Different Forms of Periradicular Diseases. Journal of Endodontics.

Saatchi, M., Shokraneh, A., Navaei, H., Maracy, M.R., Shojaei, H., 2014. Antibacterial effect of calcium hydroxide combined with chlorhexidine on Enterococcus faecalis: a systematic review and metaanalysis. Journal of Applied Oral Science.

Shlezinger, M., Friedman, M., Houri-Haddad, Y., Hazan, R., Beyth, N., 2019. Phages in a thermoreversible sustained-release formulation targeting E. faecalis in vitro and in vivo. PLOS ONE.

Siddique, R., Nivedhitha, M.S., 2019. Effectiveness of rotary and reciprocating systems on microbial reduction: A systematic review. J. Conserv. Dent. 22, 114-122.

Siddique, R., Nivedhitha, M.S., Jacob, B., 2019a. Quantitative analysis for detection of toxic elements in various irrigants, their combination (precipitate), and para-chloroaniline: An inductively coupled plasma mass spectrometry study. J. Conserv. Dent. 22, 344-350. Siddique, R., Sureshbabu, N.M., Somasundaram, J., Jacob, B., Selvam, D., 2019b. Qualitative and quantitative analysis of precipitate formation following interaction of chlorhexidine with sodium hypochlorite, neem, and tulsi. J. Conserv. Dent. 22, 40-47.

Signoretti, F.G.C., de Almeida Gomes, B.P.F., Montagner, F., Tosello, F.B., Jacinto, R.C., 2011. Influence of $2 \%$ chlorhexidine gel on calcium hydroxide ionic dissociation and its ability of reducing endotoxin. Oral Surgery, Oral Medicine, Oral Pathology, Oral Radiology, and Endodontology.

Silva, L.L.C.E., Cosme-Silva, L., Sakai, V.T., Lopes, C.S., Silveira, A.P.P. da, Moretti Neto, R.T., GomesFilho, J.E., Oliveira, T.M., Moretti, A.B. da S., 2019. Comparison between calcium hydroxide mixtures and mineral trioxide aggregate in primary teeth pulpotomy: a randomized controlled trial. J. Appl. Oral Sci. 27, e20180030.

Silva, S., Alves, N., Silva, P., Vieira, T., Maciel, P., Castellano, L.R., Bonan, P., Velozo, C., Albuquerque, D., 2019. Antibacterial Activity of Rosmarinus officinalis, Zingiber officinale, Citrus aurantium bergamia, and Copaifera officinalis Alone and in Combination with Calcium Hydroxide against Enterococcus faecalis. BioMed Research International.

Siqueira, J.F., Lopes, H.P., 1999. Mechanisms of antimicrobial activity of calcium hydroxide: a critical review. International Endodontic Journal.

Smaïl-Faugeron, V., Glenny, A.-M., Courson, F., Durieux, P., Muller-Bolla, M., Fron Chabouis, H., 2018. Pulp treatment for extensive decay in primary teeth. Cochrane Database Syst. Rev. 5, CD003220.

Stuart, C., Schwartz, S., Beeson, T., Owatz, C., 2006. Enterococcus faecalis: Its Role in Root Canal Treatment Failure and Current Concepts in Retreatment. Journal of Endodontics.

Tammannavar, P., Pushpalatha, C., Jain, S., Sowmya, S.V., 2013. An unexpected positive hypersensitive reaction to eugenol. BMJ Case Rep. 2013.

Teja, K.V., Ramesh, S., Priya, V., 2018. Regulation of matrix metalloproteinase-3 gene expression in inflammation: A molecular study. J. Conserv. Dent. 21, 592-596. 